\title{
THE "PUTTING TERRITORIES INTO TOURISM", A TOURISM DIAGNOSIS TOOL CASE OF THE WILAYA OF ALGIERS
}

\author{
Linda-Sabrina ALLOUI-AMI MOUSSA* \\ ENST (National Superior School of Tourism), Hotel Aurassi, Bv Franz Fanon, les Taggarins Algiers, Algéria, e-mail: alindasab_enst@yahoo.fr
}

Citation: Alloui-Ami Moussa, L.S. (2021). THE "PUTTING TERRITORIES INTO TOURISM", A TOURISM DIAGNOSIS TOOL CASE OF THE WILAYA OF ALGIERS. GeoJournal of Tourism and Geosites, 35(2), 456-463. https://doi.org/10.30892/gtg.35225-672

\begin{abstract}
Putting territories "on the tourism" seems to have become an unavoidable practice for all countries, regions and cities that wish to receive a share of the manna generated by tourism. This is the case of Algiers, the capital of Algeria, which has a proven but unfortunately badly exploited tourist potential. The objective of this study is to propose another approach in the elaboration of the strategy of tourist development of the wilaya of Algiers. The article thus aims at identifying effectively the real tourist dimension of the territory of Algiers.To do this, the method developed by the Equipe MIT was used, based essentially on a precise diagnostic tool integrating relevant variables, both socio-economic and environmental. Thus, the study of these ten variables showed that even if certain factors go against the development of tourism, such as the weak reactivity of the public authorities or a rate of tourist function almost null, the majority of these variables are favourable to the development of the tourist activity and to the " putting in tourism " of this territory. Thus, the wilaya of Algiers is a city with a tourist function and meets all the conditions of success for its development as a tourist destination.
\end{abstract}

Key words: Putting "into tourism", territory, variable, destination, Algiers

\section{INTRODUCTION}

Nowadays, tourism uses territories as a show. A stage where important events unfold and reveal a rich heritage, mythical places and memorable landscapes. This is why tourism is considered an important tool for the economic regeneration of the city. The cities, especially the large cities, form the most important touristic destination in the word; therefore, they receive local and international tourists (Benghadbane and Khries, 2020). In Algeria, we can say that global territorial strategies have only been present since 1989 with development schemes on a national and regional scale (Ministry of Spatial Planning, Environment and Tourism, 2008). The development of tourism strategies through instruments such as the Tourism Development Master Plan "SDAT" and the Wilaya Tourism Development Master Plans "SDATW" are today at the heart of the action plans for the redeployment of the national economy (Alloui-Ami Moussa, 2015). The tourism has become a national priority, with the consolidation of a master plan for tourist development, which focuses on the establishment of seven tourist centers of excellence (Kherrour et al., 2016). It is the greatest challenge facing the Algerian economy today (Rahal et al., 2020). However, the development of tourism in Algeria, in each wilaya, involves new questions of spatial, economic, social and cultural nature, which must henceforth be faced. Tourism activity and the tourist function should be an integral part of the policy and strategy of national development and local authorities (AOM INVEST-ANDT, 2019). The territory provides tourism with the resources to develop a tourist offer and an image of the destination, based on the combination of these resources. In terms of infrastructure development and equipment, the territory of the wilaya is largely endowed. It is constantly changing, and these developments are challenges for the organisation of space, the preservation and enhancement of natural resources, and economic development through the creation of jobs and activities for the populations. In this context, one wonders how a territory such as the ilaya of Algiers, which is endowed with innumerable tourist facilities, can benefit from them? And to what extent can its "tourism development" bring added value in the implementation of its tourism strategy for 2030?

\section{LITTERATURE REVIEW}

\section{The territory: the first resource of tourism}

In the classical approach, the territory is called "space" and is considered as a support that offers resources that can be transformed into assets. In fact, these activities are based on a set of attractions which include natural attractions such as scenic moutain and valleys, parks, lakes, wildlife, caves, and underground formations. What characterises a territory is both the range of landscapes it offers for visual discovery, and the heritage and culture it harbours. We are moving from an approach where the territory is defined as an environment, i.e. as a set of historical-socio-cultural factors that are established in the local community and institutions, to an approach where the territory is above all a network. In other words, the space-territory is not the only one that creates the behaviours of the actors; the latter in their diversity also participate in the creation of this spaceterritory not only through their own behaviours but also through the interrelations they build between them (Merasli, 2012; Lascu et al., 2018). Murphy in 2013, states that the continued attractiveness of a territory is articulated through material and functional changes that challenge traditional political-territorial arrangements. Thanks to its landscape, topographical and 
human components, the territory can be considered as the real raw material of tourism. The resource territory, taken here as an example, gathers unavoidable factors such as accessibility, water, healthiness, reception capacities, sites and socio-cultural heritages. Other forms of resources include cultural events, festivals and vintage buildings (Lozato-Giotart et al., 2012; Rajesh, 2013; Rajesh, 2014). Therefore, the tourist attractiveness of territories must be understood in its double dimension: attracting and retaining income or the populations that generate this income. Moreover, the attraction of external income is one of the stages of territorial development (Hellal, 2017). Thus, 'the territory is the object of a marketing strategy because it is a question of promoting and enhancing it in order to attract and retain different targets. It becomes the object of an abranding strategy, where the development of a specific identity is targeted and the management of its image is planned for the more or less long term' (Vuignier, 2018:23). It is always useful that policy interventions in the field of tourism must take into account the specific issues of the territories to be implemented in order to promote desirable impacts (Niavis et al., 2021).

\section{From territory to destination}

The concept of destination is widely used in tourism both in the professional and scientific community (Kadri et al., 2011). In a geographical approach to tourism, the tourist destination would designate the place where the promoted, recognised and elected space allowing individuals to escape from constraints through tourist mobility (Bédard, 2011). In the long term, the competitiveness of tourism depends on the sustainable use of territorial assets: the differentiation of destinations depends on the integration of land-based cultural natural resources in the tourism offer, but also on their preservation over time (Romão et al., 2017). However, the difficulty of conceptualising the notion of destination is not without consequences for managerial practices (Roult et al., 2019). Indeed, the perimeter of a destination is equivalent to administrative boundaries (nation, region) if they reflect strong cultural orientations, but the destination can also represent specific geographical characteristics or particularities. However, it is questionable whether these boundaries are the most desirable spatial configurations for facilitating tourist flows and service management in a geographical area (Paulino et al., 2021). Territory is therefore a complex, multidimensional and constantly evolving concept. Zerouali Ouariti and Jebrane (2019), point out another aspect of the destination is its attractiveness, which according to them is not limited to the stage of destination selection, but also influences the behaviour of tourists in general. Indeed, the attractiveness of a destination is determined by its attributes. The importance of these attributes helps people to assess the attractiveness of a destination and to make destination choices. The more a destination is able to satisfy the needs of its visitors, the more attractive it is perceived to be and the more likely it is to be chosen as a final destination. According to Tsiotas et al. (2021), one major property of tourism that affects almost all destinations in a diverse way should also be taken into consideration, namely that related to the phenomenon of (so-called) seasonality of tourism and that concerns the uneven distribution of tourism demand over the period of the year. In another context, the focus is now on 'smart destinations' (SDs), which are considered by Gretzel et al. (2015), as a key element of the smart tourism ecosystem, which is mainly based on the widespread use of technology and data by different agents. However, and according to Ivars-Baidal et al. (2021), to date there is no system of indicators to measure the progress of destinations against the expectations and goals set by the smart tourism literature and discourse.

\section{The "putting into tourism": A diagnostic tool}

Generally speaking, the expression "Putting into tourism" refers to the process of transformation of a place through tourism. The term "putting into tourism" is preferred to "touristification" because in the confusion surrounding the process and the frequent invocation of natural interventions (Ojeda and Kieffer, 2020)."Putting into tourism" has the advantage of emphasising the dynamic and human character of the action, according to Dewailly et al. (2005), the process and the resulting state of a more planned, more voluntarist, controlled, if not mastered development applying to the same objects. The role of local decision-makers and actors, apart from individuals and private companies, seems more important in the elaboration of the decision-making processes which provoke or accompany the development of tourism. In the end, for a place to become a tourist destination, a system of actors must function, through the junction between the initiatives of the first tourists and those of the other actors, including the State. Landel et al. (2014), explain that the analysis of the role of tourism in the construction of territorial resources is very instructive. The revelation of objects with attributes specific to a territory and prized by foreigners contributes to the construction of a tourist destination combining both market and non-market goods. Non-market goods can be used to develop "alternative" forms of tourism. The emergence of tourist territories across the planet makes us observe that the transformation of places for tourist purposes (called putting into tourism) seems to have become an unavoidable practice for all countries, all regions and all cities that wish to receive a share of the manna generated by tourism. This tourism development is appreciated first of all according to an economic process through the contribution of foreign currency and space through the development of places, while its implications also, if not more so, concern the society within which this process is organised (Kadri et al., 2019). Thus, culture, history, economy, architecture, landscape, social development as well as infrastructure combined in a unified whole as an identity of the territory, can be sold and accepted by everyone as a brand image (Miftahuddin et al, 2021).

\section{METODOLOGY}

The object of the study is to examine the situation of the development of tourism in the wilaya of Algiers. To do this, we opted for a territorial diagnosis highlighting the state of the territory of the wilaya of Algiers in terms of attractive potentialities which constitute the real tourist offer of this territory and whose stakes are essential in any construction of a new tourist destination (Gollain, 2019). In this diagnosis of the territory, we have adopted the method of the EquipeMIT (2000), whose relevance is still relevant according to the work carried out by Knafou in 2018. This method is a tool which targets the most significant aspects of a territory's tourism endowments and allows the conditions for successful tourism 
development to be analysed. It is based on the study of 10 variables selected as significant indicators, both socio-economic and environmental, and each of these variables is evaluated according to three levels of assessment, either quantitative or qualitative. The results obtained will be represented on a diagram made for this purpose (Figure 3). Thus, the aptitudes of the various places of Algiers to be "put in tourism" will be clearly identified.

\section{SITE OF THE STUDY}

Algiers, capital of Algeria, is a territory with a natural site and an urban history. It occupies the heart of the northern region of the country with a surface area of $809.22 \mathrm{Km}^{2}$, organised administratively into 13 Daïras grouping 57 Communes. It is situated globally on the strip limited by the Mediterranean Sea on the one hand and by the Tellian Atlas on the other. In terms of the shape of the natural site, it evolves around a crescent-shaped bay with two peaks, the Casbah and Tamenfoust. It is also a sloping configuration, with the lowest altitudes on the sea side. This is what gives Algiers this amphitheatre shape, with the coastal part as a stage, and the terraces which are the extensions of the city centre, and on the heights cer tain secondary centres of Algiers (Côte, 2006; ONT, 2011) (Figure1a and 1b).

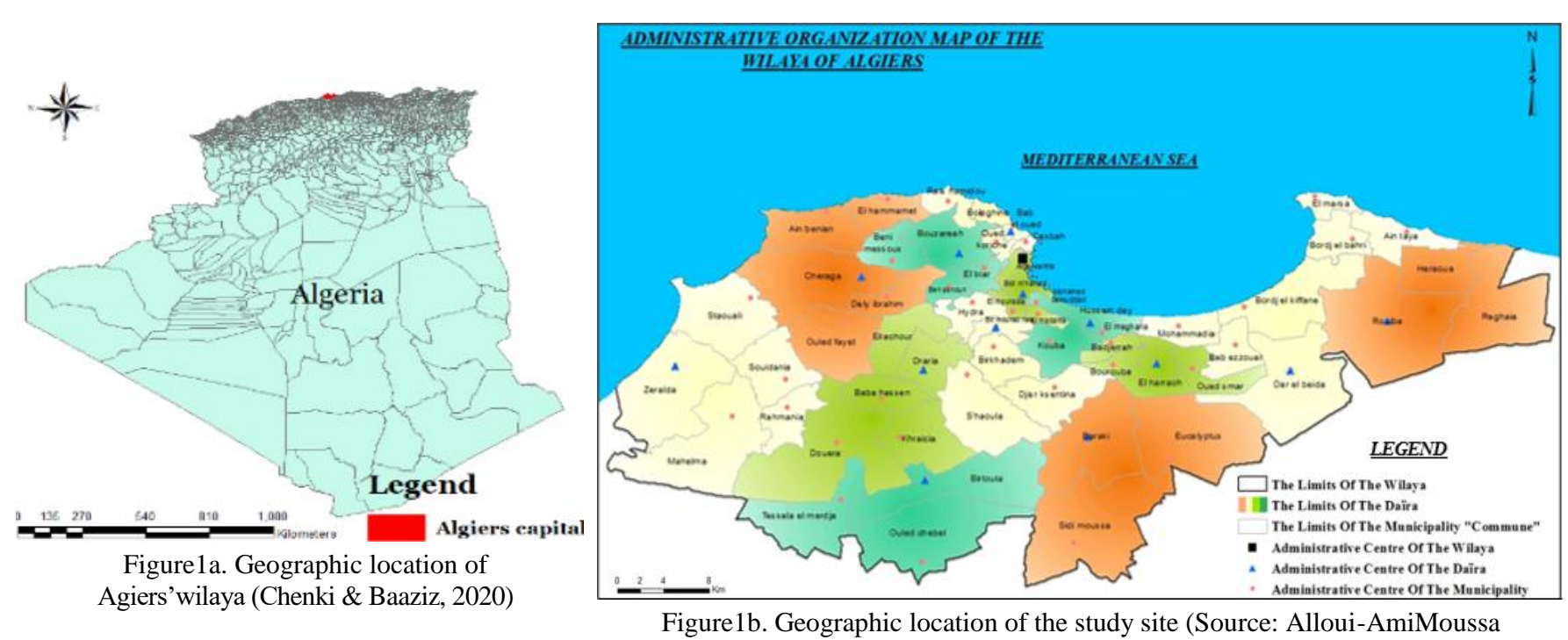

\& Lazri in Ceneap, 2017, Personal treatement for researchers, 2021)

\section{ANALYSIS OF VARIABLES}

\section{Variable 1: The tourist function rate}

This index is a very useful tool for examining tourist activity in areas where most accommodation is in the form of hotels and motels (Keogh, 1984). A tourist operating rate equal to 100 means that the place in question can receive as many tourists as permanent inhabitants; this means that it therefore doubles its population in high season, which is why it is chosen as a significant threshold. A tourist operating rate of less than 100 means that the place in question is not able to receive a good number of tourists in high season (Equipe MIT, 2000). This rate (formula 1) refers to the ratio between the total capacity of tourist accommodation and the number of permanent inhabitants of a place, as its explained by (Simon, 2019).

Formula 1 by Simon (2019):

$$
\text { Rate Tourist function }=\frac{\text { (total capacity of tourist accommodation } x 100)}{\text { number of permanent inhabitants of place. }}
$$

According to the Directorate of Tourism and Handicrafts of Algiers' wilaya, the total capacity of tourist accommodation in the wilaya of Algiers for 2019 has been estimated at 34,000 beds, while the overall population for the same year was 3, 732,209 (ONS, 2020). In the case of Algiers's wilaya, a rate of tourist function equal to 0.910 is at a really lower level compared to the significant threshold set at 100, and evokes a situation of very low "touristicity" of our territory.

$$
\text { Rate Tourist function }=\frac{(34000 \times 100)}{3732209}=0.91
$$

\section{Variable 2: Tourist numbers}

The presence of tourists in a place is not necessarily related to an accommodation function, a place cannot be touristic without tourists, hence the need to know the tourist attendance in a place (Leroux and Pupion, 2014). Based on the Equipe MIT case studies, it was shown that when attendance was below 10,000 people per year, the sites mainly hosted only visits from the local population. Between 10,000 and 50,000 visitors, the share of tourist visits becomes significant. Above 50,000 visitors per year, the site can be considered as tourist. As far as our case study is concerned, the wilaya of Algiers is frequented for its cultural, seaside, urban and Meetings, Incentives, Conferencing et Exhibitions tourism. It counted nearly 943,110 national tourists and about 689,365 foreign tourists, a total of 1,632,475 tourists. (Directorate of Tourism and Traditional Industries of Algiers's wilaya, 2020). On the basis of the figures given above, the wilaya of Algiers is therefore considered as a tourist city in terms of attendance. 


\section{Variable 3: Weight of secondary residence}

The presence of second homes counts in the apprehension of tourist areas. Areas that are already tourist areas generally have more than $50 \%$ of second homes in the total housing stock. Three thresholds have been defined to characterise non-tourist areas (Equipe MIT, 2000):

- Second homes account for less than $25 \%$ of the total, which means that we are really in living spaces,

- Second homes account for $25 \%$ to $50 \%$ of the total, we are in transitional spaces between permanent living spaces and tourist areas,

- Second homes account for more than $50 \%$ of the total, they are tourist places, including holiday homes and not just weekend homes.

In our case study, there are no official figures on second homes. However, according to the estimates of the Algiers's tourism and crafts directorate, there are no secondary residences dedicated to holidays, but secondary residences used for renting to the populations living and working in the wilaya of Algiers. The percentage of these secondary residences is then estimated at less than $25 \%$ of the total housing stock, which shows us that the wilaya of Algiers is a living space.

\section{Variable 4: Economic dynamics}

Tourism is unlikely to develop in areas that do not have an economic need for it. Where agriculture or industry is thriving, tourism development can be counterproductive. On the other hand, if the dominant sector runs out of steam, tourism development becomes possible, and may accelerate the decline of the former activity. This occures because in our world economy, the weight of the productive sectors is decreasing while the share of services (including tourism) is growing (Kolosinska et al., 2018). Then, if the dominant sector is in crisis, tourism becomes the activity of the last chance. As far as the wilaya of Algiers is concerned, and on a larger scale, in Algeria, tourism is considered as one of the alternatives to the hydrocarbons sector, a vector of development of the economy, in a period when there are hydrocarbon price crises (Hadjiedj, 2008). The development of new services will generate new employment opportunities for the improvement of local revenues (Kherrour et al., 2020). Algiers is considered to be the most dynamic and attractive territory in terms of population and investment flows (Ceneap, 2019). This centrality makes it:

- The focal point of national political-administrative life. As such, it exerts a strong tropism on its regional and national environment.

- The hub of the non-hydrocarbon economy, which has unrivalled productive capacities, hosts the main strategic decision-making centres, concentrates the centres of higher education and research and attracts the bulk of the FDI, which is heading for Algeria.

- The major centre of cultural influence, due to the density and diversity of its heritage, the density of its culinary and musical traditions and the richness of its event offer, which make it a rising metropolitan tourist destination, due to its provision of large-scale urban development and world-class hotel facilities (UNWETO-PNUD, 2020). The territory of Algiers is equipped with several functionalities having a direct relationship with the services and takes advantage of the tourist flows that frequent its territory. Tourism therefore contributes to the economic dynamics of the capital of the country.

\section{Variable 5: The evolution of the tertiary labour force}

This evolution is another relevant criterion, since tourism implies a strong development of the service field. This evolution is generally distinguished in the comparison of the last two censuses of the country, concerning employment. Three scenarios were selected:

- The proportion of this active population in the tertiary sector has remained or become less than $50 \%$ of the total: the situation is not a priori favourable to the rapid development of tourism.

- The proportion of the active population in the tertiary sector has become more than $50 \%$ of the total: This may mean that the activity (agriculture or industry) that used to be dominant

Table 1. The active population of the wilaya of Algiers (Source: made by the author based on ONS, 2015 \& 0NS, 2019)

\begin{tabular}{|c|c|c|}
\hline Criteria Year & 2015 & 2019 \\
\hline Total labour force & 1382713 & 1562785 \\
\hline Tertiary labour force (trade and services) & 639952 & 739220 \\
\hline Percentage (\%) & $46,28 \%$ & $47,30 \%$ \\
\hline
\end{tabular}
is experiencing a decline.

- The propotion of the active population in the tertiary sector has been and remains above $50 \%$ of the total : These are, in the broadest sense, urbanised areas or areas in contact with cities or tourist locations.

The distribution of the occupied population by branch of activity in the wilaya of Algiers was estimated for the year 2019 on the basis of the reference year of 2015 and statistical data from the national statistics office (Table1).

We note that the share of this population was and remained below $50 \%$, we conclude that the situation is not a priori favourable to the rapid development of tourism in Algiers.

\section{Variable 6: Change in net migration}

When a place loses inhabitants, it goes through a period of crisis, which offers the possibility of a change of use, with the remaining population seeking solutions so that the place can continue to exist and be open to innovation; but conversely, the decline of a place can correspond to a radicalisation of the remaining inhabitants, rejecting an outsider considered to be the author of this decline. Three scenarios can be retained according to the variation between two censuses (Equipe MIT, 2000):

- The migratory balance has remained negative, or a positive balance has become negative : the place is emptying or has been emptied, the space is undergoing transformation;

- The balance, previously negative, has become positive ; this reversal can mean at least three possibilities: 
$\checkmark$ either a certain number of tourist actions have already been launched and they are beginning to have an effect on the settlement of permanent population;

$\checkmark$ or the setting up of a company of any kind boosts the economic activity of the place and thus the installation of people ;

$\checkmark$ or the place is affected by the redistribution of the population; in any case, the place in question becomes or becomes again a place to live; but tourism must be developed in a place where the tourist dynamic is already underway or in a place where a new use is being put in place;

- The balance remains positive, the place continues to attract. According to national statistics office:

$\checkmark$ Population of the wilaya of Algiers at the time of the 1998 RGPH: 2,562,428 inhabitants.

$\checkmark$ Population of the wilaya of Algiers at the time of the 2008 RGPH: 3032967 Inhabitants.

$\checkmark$ Population of the wilaya of Algiers in the year 2018: 3658228 Inhabitants.

$\checkmark$ Population of the wilaya of Algiers in the year 2019: 3. 732209 Inhabitants.

- Migration balance (1) = Population in 2008- Population in 1998

- Net migration (1) = 3032 967-2 562 428= 470539 inhabitants

- Migration balance (2) = Population in 2018 - Population in 2008

- Net migration (2) = $3658228-3032967=625261$ habitants

- Migration balance (3) = Population in 2019- Population in 2018

- Net migration (3) = 3732 209- $3658228=73981$ habitants

Over the 3 periods studied (2008, 2018 and 2019), it can be noted that the migratory balance of the wilaya of Algiers has been and remains positive, therefore that the wilaya of Algiers is an attractive city capable of attracting tourists.

\section{Variable 7: Role of local actors}

The role of elected representatives can be divided into three main families of behaviour when faced with a tourism development project: hostility or passivity; a project carried by elected representatives; and the intervention of a high level leader, i.e. the political personality who, through a network of knowledge and relations resulting in the arrival of subsidies, is able to ensure the tourism development of the place or area for which he is elected. Actually, urban interventions have led to a shift in the style of life (Nogués-Pedregal, 2019). Thefore, elected representatives are open to any proposal that would allow the development of tourist activity, however they have always lacked personal initiative (Chenki and Baziz, 2020). However, some exceptions are useful to point out, in fact, we note that during the period of the minister-governor of Grand Algiers (1997-2000) who was the initiator of the "development of the Bay of Algiers" project, several operations were launched, then this project was put on stand-by for about 14 years. Afterwards, it was relaunched with the arrival of the wali of that time (2013-2019). We have thus recorded the finalisation of many projects included in the strategic plan of Algiers 2029 (Parquexpo, 2016), such as the leisure space of La Sablette, the recreational forest of Ben Aknoun and the business district of Bab Ezzouar where the large Trust Hotel \& Resorts-Marriott complex is located. In October 2020, it is the great project of Djamaa El Djazair which was received. In spite of these praiseworthy initiatives, today we note that the involvement of local officials in the tourist development of Algiers remains insufficient.

\section{Variable 8: Attitude of the local population}

Space as a resource is intensively used by both tourism and the local community. If a place becomes touristy, it is because part of the local population wants this type of development (Ouellet, 2015) Therefore, the state of tourism development needs to be measured over time, as well as the attitudes of the local population, to determine the impacts and the pressure that tourism development may continue to exert (Marković and Klarić, 2015). The attitude of residents reflects the mindset or disposition of residents towards a tourist destination and hospitality constitutes an essential factor in the selection of destinations (Kelfaoui et al, 2021). According to Dangi and Petrick (2021), tourism helps to promote cultural preservation and community pride and fosters a sense of mutual respect and understanding among visitors and stakeholders. Needing and depending on the situation, the attitude of the local population can be defined as hostile, indifferent or favourable. The population of Algiers is increasingly looking for leisure activities, relaxation and entertainment. They have always been enthusiastic about meeting people from different backgrounds. Since the country's security has improved in Algeria, society has become very favourable to the creation of tourist and leisure infrastructures. The Algiers' inhabitants, like all Algerians, are hospitable by nature and aspires to make visitors to his city discover his culture and history. They show no reluctance to meet foreigners. The Algiers' population is therefore favourable to the development of tourist activity in their wilaya.

\section{Variable 9: Geographic location}

The assessment of the geographical location of the place is measured in relation to its distance from a potential market. Three possibilities have been considered: the situation in relation to the urban market, to a major thoroughfare or to other tourist locations. The three criteria can be met (total proximity), or only one or two (partial proximity), or none (remoteness). The latter situation may not be definitive and may even, in some cases, prove to be an asset: relative inaccessibility and isolation are qualities for some tourist populations. The wilaya of Algiers occupies a central position, which gives it a proven advantage, due to the proximity of the large basins emitting tourist flows and its role as a link and confluence point in its area of belonging. The site effect enjoyed by the wilaya of Algiers constitutes an undeniable competitive advantage, which remains however notoriously undervalued in terms of tourism, as demonstrated by the weak performance of the destination (Ceneap, 2019). This geographical positioning, potentially favourable, remains a precious asset for the tourist future of the wilaya. Thanks to its status as a capital, Algiers attracts many visitors both nationally and internationally. Also, since it represents one 
of the most important metropolises of the country, through its infrastructure and tourist facilities, it is a very popular city among the Algerians. Algiers also occupies a strategic position in the Mediterranean basin and is situated close to its first emitting tourist market, which is Europe.The wilaya of Algiers thus benefits from a total proximity thanks to its geographical situation.

\section{Variable 10: Landscape character}

It is not a question of the meaning and symbolism of a landscape, or even its picturesque dimension, but rather its ability to be walked through: where it is maintained, widely or totally accessible; where it is semi-open, combining accessible and nonaccessible spaces; or where it is closed, due to exclusive activity.

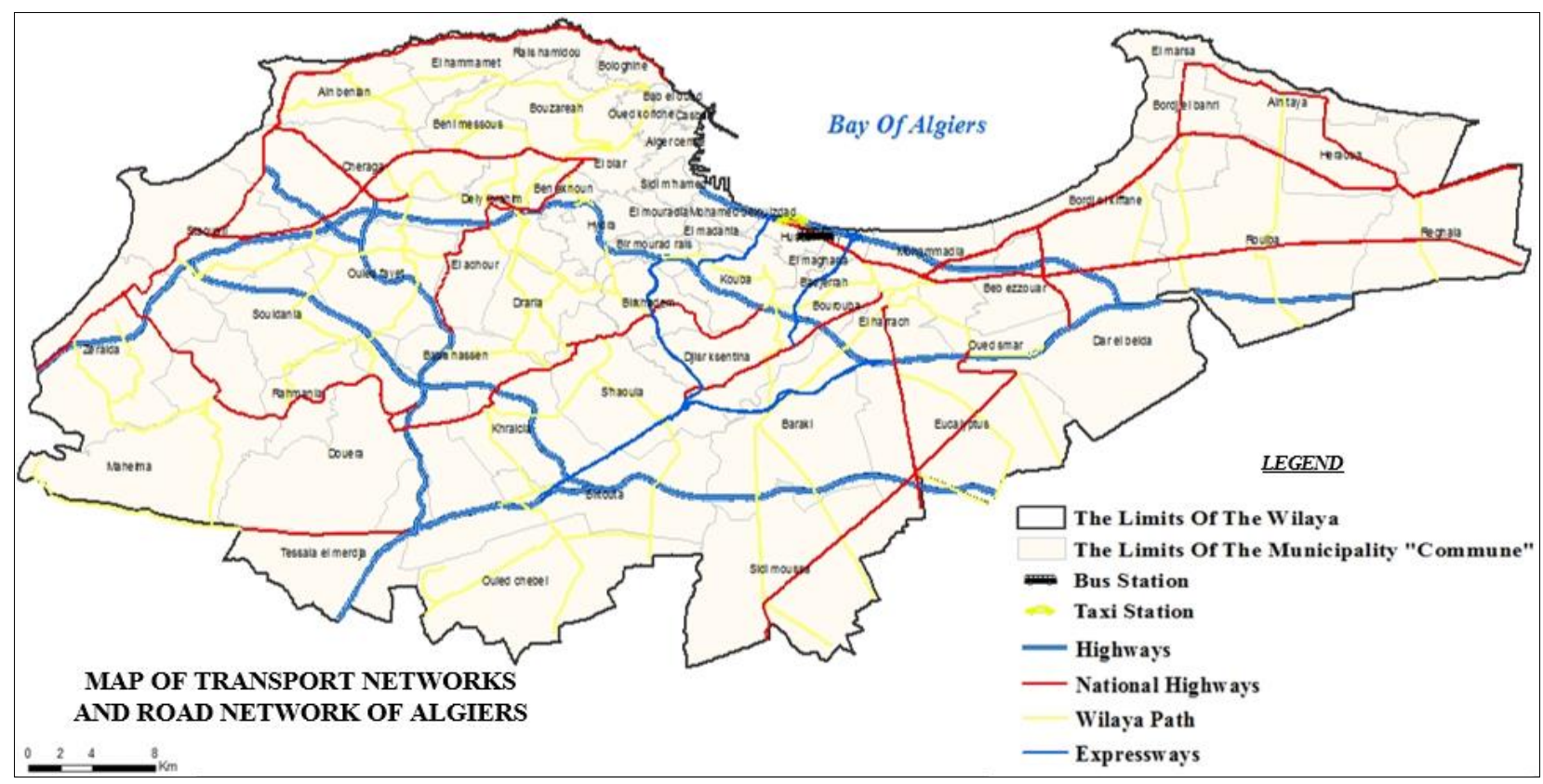

Figure 2. The accessibility of the Algiers territory (Source: Alloui-Ami Moussa \& Lazri in Ceneap, 2017, Personal treatement for researchers, 2021)

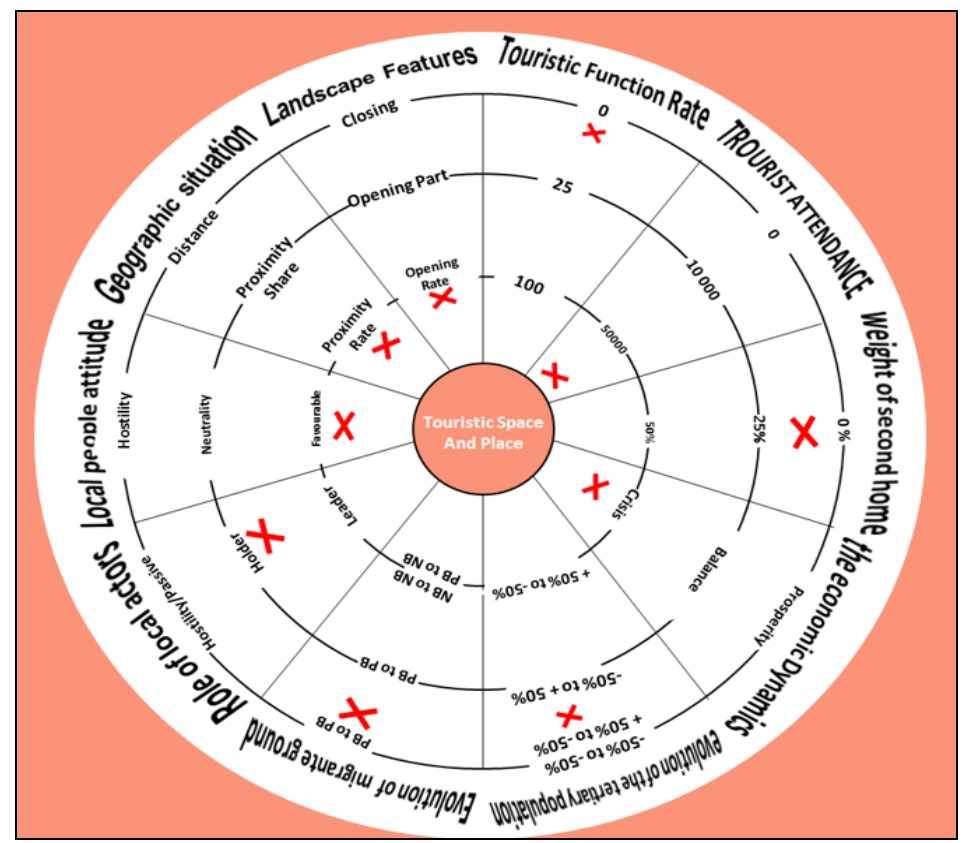

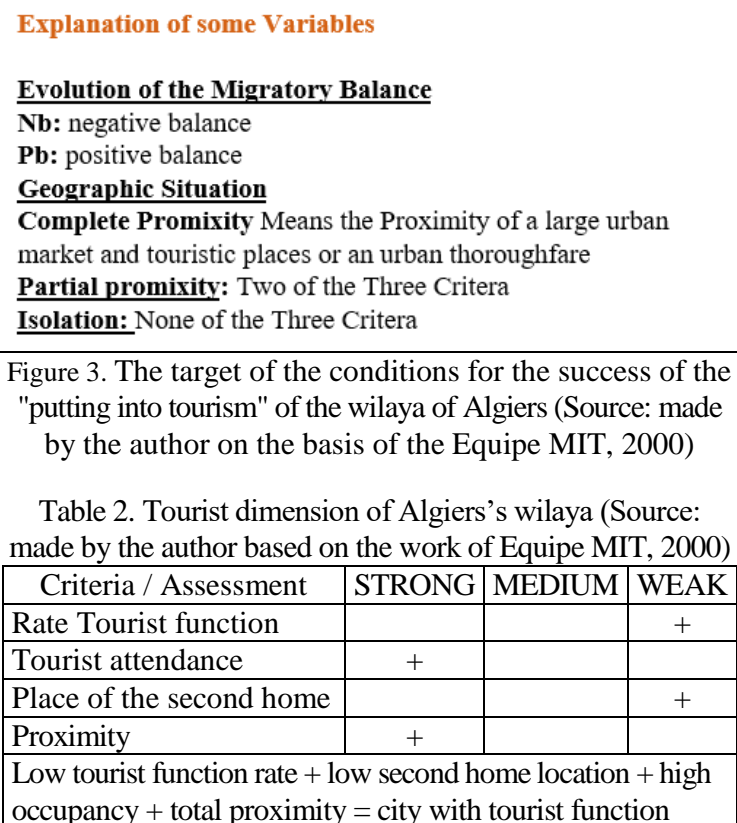

However Accessibility does not mean only the transport part, also includes access to the tourist's needed information (Biswas et al., 2020). The wilaya of Algiers is well endowed in terms of transport equipment. For air transport, the international airport of Algiers is the most important of the country's airports. The port of Algiers, for its part, enjoys a privileged geographic position in the Mediterranean basin. Internally, Algiers is accessible by road thanks to the East-West motorway and the various localities of Algiers are well served and accessible thanks to the capital's public transport macro-mesh; a collective road, tramway and cable car (Ceneap, 2017). The wilaya of Algiers thus benefits from total openness and accessibility (Figure 2).

\section{SUMMARY OF RESULTS}

None of the criteria is decisive in the development of tourism in a place. As soon as several favourable elements are brought 
together, an element of weight can be missing without compromising the operation. Finally, it is the combination of all these elements which makes it possible to apprehend the conditions for the development of tourism and its possible success (Equipe MIT, 2000). According to Knafou (2018), it is a simple and evolving reading grid, both operational in the majority of practices and open to the complex situations that our tourism system tends to produce. So, using the ten criteria and their internal division into three classes, and following Equipe MIT's methodology, we developed a target-like figure (Figure 3). At the heart are the tourist spaces and places. The closer the values for a given place are to the centre, the more favourable the conditions for tourism. For most of the criteria, a quantitative or qualitative progression from the periphery towards the centre is to be noted. Only the migratory balances and the economic dynamics propose an inverse logic. Algiers is therefore suitable for tourism as attested by $8 / 10$ of the variables, only variables 5 and 1 need to be improved. As a result, it is a city with a tourist function (Table 2).

\section{CONCLUSION}

Through the analysis of the target of the conditions of success of the « Putting into tourism » the wilaya of Algiers, it will be noted that the majority of the variables are in favour of the development of tourist activity and the touristification of Algiers's wilaya, which is undeniably a city with a tourist function. However, some factors are against a « putting into tourism », such as the growing increase in the population within the city, the low reactivity of the public authorities, the absence of second homes and finally a rate of tourist function which is almost nil. However, it should be noted that these constraining factors are for the most part taken care of and are being improved between now and 2030, through the construction of facilities serving tourist activity and by developing geotourism areas and places of visits as envisaged by the action plan of the Master Plan for Tourist devloppment of Algiers's wilaya (Ceneap, 2018). The image and perception of the destination "Algiers" are closely linked to the overall competitiveness of tourism. It should be emphasised, in this respect, that the strengthening of its presence on the markets to be conquered, requires a better visibility and increased legibility of the destination and its various components. Today, despite the progress recorded in recent years, the tourist image of Algiers still remains blurred in the imagination of potential visitors. It is strongly impregnated by the summer activity, with uncontrolled effects, and a business movement devoid of tourist sense, during the rest of the year.

\section{REFERENCES}

Alloui-Ami Moussa, L. (2015). Cours d'aménagement touristique [Tourist planning course]. Office des Publications Universitaires, Algiers, Algeria, 65. Bédar, F. (2011). L'excellence des destinations[The excellence of destinations]. Téoros, 9-11. https://doi.org/10.7202/1012103ar

Benghadbane, F., \& Khries, S. (2020). Urban touristic development in the coastal cities: Case study: Aquaba, Alexandria, Annaba and Casablanca. GeoJournal of Tourism and Geosites, 29(2), 488-507. https://doi.org/10.30892/gtg.29209-484

Biswas, C., Omar, H., \& Rashid-Radha, Y. (2020). The impact of tourist attraction and accessibility on tourist' satisfaction: The moderating role of tourist'age. Geojournal of Tourism and Geosites, 32(4), 1202-1208. https://doi.org/10.30892/gtg.29209-484

Chenki, K., \& Baaziz, A. (2020). Evaluating ability of municipalities to promote stong brand image in algerians cities. Geojournal of Tourism and Geosites, 28(01), 21-34. https://doi.org/10.30892/gtg.28102-449

Côte, M. (2006). Guide d'Algérie: Paysage et patrimoine [Guide to Algeria: Landscape and heritage], Media- Plus, Constantine, Algeria, 404.

Dangi, T.B., \& Petrick, J.F. (2021). Augmenting the role of tourism governance in addressing destination justice, ethics, and equity for sustainable community-based tourism). Tourism and Hospitality, 2(1), 15-42. https://doi.org/10.3390/tourhosp2010002

Dewailly, J., Amirou, R., \& Bachimou, P. (2005). Tourisme et souci de l'autre [Tourism and concern for others], L'Harmattan, Paris, France, 362.

Equipe MIT. (2000). La mise en tourisme des lieux: Un outil de diagnostic [The putting into tourism in places: A diagnostic tool]. Mappemonde, (57), 2-6. https://www.researchgate.net/publication/26432468

Gollain, V., (2019). Créer une destination touristique: une approche méthodologique en sept étapes [Creating a tourist destination: a methodological approach in seven steps]. Espace, 350, 45-48. https://www.tourisme-espaces.com/doc/10322.creer-destinationtouristique-approche-methodologique-sept-etapes.html

Gretzel, U., Sigala, M., Xiang, Z., \& Koo, C. (2015). Smart tourism: Foundations and developments. Electronic Markets, 25 (3), $179-188$. https://doi.org/10.1007/s12525-015-0196-8

Hadjiedj, A. (2008). Le tourisme, un secteur alternatif aux hydrocarbures[Tourism, an alternative sector to hydrocarbons]. In Tourism as a sector of an alternative economy and hydrocarbon development: Proceedings of the international colloquium, 7-10. Houari Boumediene Sciences and Technology University, Algiers, Algeria, 450.

Hellal, M. (2017). Residences des étranger dans un territoire touristique: Un phénomène flou en Tunisie[Residence of foreigners in a tourist territory: A blurred phenomenon in Tunisia] . Téoros, 36(2), 11-16. https://doi.org/10.7202/1042466ar

Ivars-Baidal, J., Celdran Bernabeu, M.A, Femenia-Serra, F., Perles-Ribes, J., \& Giner Sanchez, D.(2021). Measuring the progress of smart destinations: The use of indicators as a management tool. Journal of Destination, Marketing and Management, 19,1-20. https://doi.org/10.1016/j.jdmm.2020.100531

Kadri, B., Bondarenko, M., \& Pharicien, J. (2019). La mise en tourisme: Un concept entre déconstruction et reconstruction: une perspective sémantique ["The putting into tourisme": A concept between deconstruction and reconstruction]. Téoros, 38(1), 12-24. https://doi.org/10.7202/1059747ar

Kadri, B., Khomsi, M., \& Bondarenko, M. (2011). Le concept de destination[The destination concept]. Téoros, 30(1), 10-22. https://doi:10.7202/1012104ar

Kelfaoui, A., Rezzaz, A.M., \& Kherrour, L. (2021). Revitalization of mountain rural tourism as a tool for sustainable local development in kabylie (Algeria). The case of Yakouren municipality. GeoJournal of Tourism and Geosites, 34(1), 112-125. https://doi.org/10.30892/gtg.34115-626

Keogh, B. (1984). The measurement of spatial variations in tourist activity. Annal of Tourism Recherche, 11(2), $267-287$. https://doi.org/10.1016/0160-7383(84)90074-4

Kherrour, L., Hattab, S., \& Rezzaz, M. (2020). Archaeological sites and tourism: Protection and valorisation, case of Timgad(Batna) Algeria. GeoJournal of Tourism and Geosites, 28(1), 289-302. https://doi.org/10.30892/gtg.28123-470

Kherrour, L., Souiher, N., \& Drias, A. (2016). Towards the development of eco-cultureltouris in the Ghoufi area, Batna Algéria. Review Geographia Napocensis, X(1), 1-13. http://geographianapocensis.acad-cluj.ro/Revista/volume/nr_1_2016/pdf/Napocensis-BT_1.pdf.

Knafou, R. (2018). L'expérience de l'Équipe MIT (Mobilités, Itinéraires, Tourismes), premier groupe français de recherche sur le tourisme: une aventure humaine et intellectuelle [The experience of the "Équipe MIT», first french research group on tourism. A human and intellectual adventure].Bulletin de l'Association des Géographes Français, 95(4), 455-467. https://doi.org/10.4000/bagf.3905 
The "Putting Territories into Tourism", A Tourism Diagnosis Tool Case of the Wilaya of Algiers

Kolosinska, M., Petrashchak, O., Kolosinskyi, I., \& Katana, A. (2018). Tourism sector in transition economy on example of Ukraine: Determnants of competitiveness. GeoJournal of Tourism and Geosites, 21(1), 239-252. https://doi.org/10.30892/gtg.21119-284

Landel, P., Gagnol, L., \& Oiry-Varacca, M. (2014). Territorial ressources and tourist destination: Couple with a bright futur? The cases of saffron productionat Taliouine(Morocco) and onion production in the Aïr(Niger). Journal of Alpine Research, 102(1), 1-16. https://doi.org/10.4000/rag.2334

Lascu, D.N., Manrai, L.A., Manrai, A.K., \& Gan, A. (2018). A cluster analysis of tourist attractions in Spain: Natural and cultural traits and implications forglobal tourism. European Journal of Mangement and Buisness Economics, 24(3), 218-230 https://doi.org/10.1108/EJMBE-08-2017-0008

Leroux, E., \& Pupion, P. (2012). Management du tourisme et des loisirs [Tourism and leisure management], Magnard-Vuibert, Paris, France, 304.

Lozato-Giotar, J., Leroux, E., \& Balfat, M. (2012). Management du tourisme: Territoires, offres et stratégies [Tourism management:Territories, offers and strategies], Pearson, Paris, France, 376.

Marković, I., \& Klarić, Z. (2015). Attitudes of local population of tourism impacts on destination sustainability: case of Croatia. Turizam, 19(3), 98-110. https://doi.org/10.5937/Turizam1503098M

Merasli, S. (2012). Attractivité durable des destinations touristiques [Sustainable attractiveness of tourist destinations], Belzac, Paris, France, 203.

Miftahuddin, A., Hermanto, Raharja, S.J., \& Chan, A. (2021). City branding and its variables: the evidence from Indonesia. GeoJournal of Tourism and Geosites, 34(1), 240-244. https://doi.org/10.30892/gtg.34132-643

Murphy, A.B. (2013). Territory's continuing allure. Annals of the Association of American Geographers, 103 (5), 12121226. https://doi.org/10.1080 / 00045608.2012.696232

Niavis, S., Papatheochari, T., Koutsopoulou, T, Coccossis, H., \& Psycharis, Y. (2021). Considering regional challenges when prioritizing tourism policy interventions: evidence from a mediterranean community of projects. Journal of Sustainable Tourism, $29,1-22$. https://doi.org/10.1080/09669582.2021.1876074

Nogués-Pedreal, A. (2019). The instrumental time of memory: local politics and urban aesthetics in a tourism context. Journal of Tourism Analysis, 26(1), 2-24. https://doi.org/10.1108/JTA-05-2018-0014

Ojeda, A.B., \& Kieffer, M. (2020). Touristification. An empty concept or an analytical element in tourism geography? Geoforum, 115, 143145. https://doi.org/10.1016/j. geoforum.2020.06.021

*** ONT. (2011). Guide pratique d'Algérie: 48 wilayas d'Algérie [Practical guide to Algeria: 48 wilayas of Algeria]. Nounou édition, Algiers, Algeria, 180.

Ouellet, A. (2015). Dinan en représentation(s): Patrimonialisation et mise en tourisme d'une petite ville historique de Bretagne [Representations of Dinan. Heritage-making and development of tourism of a small historic city in Brittany]. Norois, 234, 47- 63. https://doi.org/10.4000/norois.5572

Paulino, I., Lozani, S., \& Prats, L. (2021). Identifying tourism destinations from tourists' travel patterns. Journal of Destination, Marketing and Management, 19, 1-13. https://doi.org/10.1016/j.jdmm.2020.100508

Rahal, W., Rezzaz, M.A., \& Kherrour, L. (2020). The preservation of world archaeological sites and promotion of tourism: qala'at bani hammad (M'sila) Algeria. GeoJournal of Tourism and Geosites, 33(4spl), 1571-1578. https://doi.org/10.30892/gtg.334spl19-610

Rajesh, R. (2013). Impact of tourist perceptions, destination image and tourist satisfaction on destination loyalty: A conceptual model, PASOS. Journal of tourism and Cultural Heritage, 11(33), 67-78. https://doi.org/10.4090/juee.2008.v2n2.033040

Rajesh, R. (2014). Impact of tourist perceptions and satisfaction on destination loyalty: A case of Puducherry tourism, Doctoral disertation. Pondicherry University, Pudicherry, India, 264.

Romão J., Guerreiro, J., \& Rodrigues, P. (2017). Territory and sustainable tourism development:a space-time analysis on european regions. The Journal of ERSA, 4(3), 1-17. https://doi.org/10.18335/region.v4i3.142

Roult, R., Khomsi, M.D., \& Drouin, M. (2019). Les destinations touristiques à l'épreuve des marques de territoire: Introduction [Territorial branding of tourist destinations: An introduction]. Téoros, 38(1). https://doi.org/10.7202/1065642ar

Simon, A. (2019). Tourisme, fondamentaux et techniques[Basic and technical tourism], Dunod, Paris, France, 327.

Tsiotas, D., Krabokoukis, T., \& Polyzos, S. (2021). Detecting tourism of regional destinations based on their spatio-temporal and socioeconomic performance: A correlation-based complex network approach for the case of Greece. Tour.Hosp, 2,113-139. https://doi.org/10.3390/tourhosp2010007

Vuignier, R. (2018). Attractivité des territoires et place branding[Attractiveness of the territories and branding],Doctoral thesis, University of Lausane, Lausane, Switzerland, 276. http://serval.unil.ch/

Zerouali Ouariti, O., \& Jebrane E.M. (2019). Attractivité touristique et logistique territoriale: Cas d'étude de la ville de Marrakech [Tourist attractiveness and territorial logistics: Case study of the city of Marrakech]. IOSR Journal of Business and Management (IOSR-JBM), 21 (6), 49-58. http://doi.org/10.9790/487X-2106024958

*** AOM-INVEST-ANDT. (2019). Evaluation du schéma directeur d'aménagement touristique 2030, période 2008-2018[Evaluation of the tourism development master plan 2030: period 2008-2018]. Algiers, 130.

*** Ceneap. (2017). Le schéma directeur d'aménagement touristique de la wilya d'Alger, phase 2: Diagnostic [The master plan of tourist development of the wilaya of Algiers: phase 2/Diagnosis]. National Center for Population Studies and Analysis, Algiers, Algéria, 101.

*** Ceneap. (2018). Le schéma directeur d'aménagement touristique de la wilya d'Alger, phase 4: plan d'action et mise en oeuvre [The master plan for the tourist development of the wilaya of Algiers, phase 4: action plann and implementation]. National Center for Population Studies and Analysis, Algiers, Algéria, 76.

*** Ceneap. (2019). Le schéma directeur d'aménagement touristique de la wilya d'Alger: Rapport final [The master plan for the tourist development of the wilaya of Algiers: Final report]. National Center for Population Studies and Analysis, Algiers, Algéria, 252.

*** Directorate of Tourism and Handcrafts of Algiers' wilaya (2019). Rapport annuel d'activités [Annual activity report]. Algiers, Algeria, 75.

*** Ministry of Spatial Planning, Environment and Tourism. (2008). Le schéma directeur d'aménagement touristique 2030[The Master Plan for Tourist Development "SDAT 2030"]. Ministry of Spatial Planning, Environment and Tourism, Books 1- 5, Algiers, Algeria.

*** ONS: National statistics office (2015). Activités, emplois et chomage: Données statistiques [Activity, employment and unemployment: Statistics data]. National statistics office, Algiers, Algeria, 1-15.

*** ONS: National statistics office (2019). Activités, emplois et chomage: Données statistiques [Activity, employment and unemployment: Statistics data]. National statistics office, Algiers, Algeria, 1-20.

*** ONS: National statistics office (2020). La démographie en Algérie: Donées statistiques [Algerian Demography: statistic data. National statistics office statistics], Algiers, Algeria, 4-19.

*** PARQUEXPO. (2016). Plan directeur d'aménagement et d'urbanisme de la wilaya d'Alger [Master plan of development and urbanism of the wilaya of Algiers' wilaya]. Department of urban planning and construction, Algiers, Algeria, 170.

*** UNWTO-PNUD. (2020). The marketing strategy of tourism in Algeria. Ministry of Tourism, Handicrafts and Family Affairs, Algiers.

Article history: Received: 08.01.2021 Revised: 06.03.2021 Accepted: 04.05.2021 Available online: 25.05.2021 